\title{
Can it Ever be Wise to Kill the Tyrant?
}

\author{
Insights from Cicero in the Debate on Rightful Government \\ during the Middle Ages (Especially in the $13^{\text {th }}-14^{\text {th }}$ Centuries)
}

When creating the concept of 'civic humanism', Hans Baron regarded Cicero as a reference point of Republican ideals and 'vita civile' during the $15^{\text {th }}$ century. ${ }^{1}$ In Florence around 1400, Cicero's symbolic value changed in dialogues livening up the conflict between Florence and Milan. A political Cicero emerged from this war context, inspiring both declamation and civic involvement. An enlarged corpus of Cicero's works and a better knowledge of his biography supported this new interpretation. Prior to this, however, did medieval readers associate Cicero with a political regime? For two centuries the reflection on government had evolved significantly, influenced by Aristotelian ethics. The engagement with the moral virtues of the ruler extended to the role of the ruled people and the political regimes. Nevertheless, as I will demonstrate here, although Cicero was rediscovered as a political actor, his impact on political theory remained marginal until the end of the fourteenth century.

Among the debates that involved Cicero at the beginning of the fifteenth century, the controversy on tyranny is a particularly interesting example. The theme was continuously discussed throughout the Late Middle Ages and had a particular resonance with Cicero's thinking and biography. The debate centred around the definition of rightful government, also with the help of historical arguments, and posed ethical questions: how to act when living under tyranny? Can it ever be wise to kill the tyrant?

In the thirteenth century, nearly two centuries before Coluccio Salutati wrote his De tyranno, authors only rarely depicted Cicero as a politician. Above all, they considered him a rhetorician and an ethical philosopher. ${ }^{2}$ Nevertheless, he had

1 The observations by Baron 1966 were qualified or corrected by some historians afterwards: firstly because of his overly generalizing approach to Florentine discourse; secondly, because of discursive opportunism which humanists used in political oppositions (by borrowing from different authorities, depending on the point they wanted to demonstrate); and lastly, because rhetoric played a decisive role in the convergence of ancient knowledge and political culture in Italian comuni, placing Cicero at the intersection of these two fields. Cf. Hankins 1995; Nederman 2000. Cf., however, the plea (by Jansen in this volume) for a Republican interpretation of Bruni's Cicero nouus.

2 Cf. Mabboux (forthcoming), where I treat the late medieval reception of Cicero on a broader scale.

O OpenAccess. (C 2020 Carole Mabboux, published by De Gruyter. (cc) BY-NC-ND This work is licensed under the Creative Commons Attribution-NonCommercial-NoDerivatives 4.0 License. 
already enjoyed some success through a civic reading by 'communal authors', ${ }^{3}$ an interpretation that was helped by the general empowerment of the orator within this civic context ${ }^{4}$ and by the frequent circulation of De inuentione, De officiis, and De amicitia. Cicero's position regarding tyrannicide seemed ambivalent to a medieval reader: on the one hand, he was a Christianized moral author; on the other, he was also considered a (passive) actor in the murder of Caesar. ${ }^{5}$ Sometimes his auctorial authority and his historical persona coexisted only with difficulty. The comparison of Cicero's reflections with those of other auctoritates and the gradual discovery of his correspondence influenced the late medieval interpretation of his political and moral positions. But the question remained: how could the medieval reader follow Cicero's advice if his behaviour was in contradiction to it?

After synthesizing the literary and human attributes assigned to Cicero during the Late Middle Ages-particularly in Italy-this paper concentrates on the different definitions of tyranny constructed by communal authors and on the ways the past of the Roman Republic is used to support them. Finally, it will focus on the contributions and limits of Ciceronian influence on political thinking during the Late Middle Ages.

\section{Defining a medieval Cicero}

\section{A limited corpus: standards of speech and behaviour}

What did a medieval reader know about Cicero's life and works? Cicero was the undisputed master of rhetoric during the Middle Ages: the trivium elected him magister eloquentiae in Late Antiquity. ${ }^{6}$ De inuentione and Rhetorica ad Herenni-

\footnotetext{
3 I use the term 'communal' with reference to authors and literature in the context of the society of the Italian comune of the Late Middle Ages.

4 Communal literature of the second part of the thirteenth century saw a strong link between rhetoric and politics. In a government with heavy emphasis on the discussion during assemblies, civic engagement implied speaking. The libri de regimine and the rhetorical treatises depicted the involved citizen as an eloquent and prudent orator, aware of the power that eloquence gives him. On this topic, see Artifoni 2006, 2012.

5 At the same time, Cicero's death was itself attributed to tyrants, according to some verses from the Anthologia Latina (Anth. Lat. 608.5-6 Riese): Hunc tamen (o pietas!) tres occidere tyranni; / at Lamia ille pio subposuit tumulo ("However, three tyrants killed him, but Lamia placed him in a pious grave"). The Anthologia Latina, a collection of Latin poems, most of them composed during the Imperial Age, was a common reference for medieval authors, cf. Zurli 2017.
}

6 Murphy 1974, 106-107. 
um (mistakenly attributed to him) were the most copied Ciceronian texts during the thirteenth and fourteenth centuries. However, Cicero was a master without students. Medieval teachers generally considered his advice as outdated; handbooks made only few references to him. ${ }^{7}$ His judicial rules were reframed to fit written rhetoric, primarily expressed as ars dictaminis (the art of letter writing). ${ }^{8}$ Despite these adjustments, Cicero was generally considered the embodiment of rhetoric. ${ }^{9}$

Cicero, after having been Christianized by the Church Fathers, was also a moral figure. Especially three texts of his final years were highly successful, which is partially reflected by the high number of copies: De officiis, De amicitia, and De senectute. They gained greater importance from the end of the twelfth century, even though the Italian curricula still excluded them during this period. ${ }^{10}$ Their quotations were, however, omnipresent in moral florilegia. Cicero's Christianized morals traditionally guided the ecclesia, ${ }^{11}$ but during the thirteenth century, they were gradually applied to civic rules. In an Italian context, this development coincided with the increasing influence of a 'social' Aristotle (Nicomachean Ethics, Politics), whose works were quoted and progressively translated. From the 1240s, because of the increased diffusion of the eighth and ninth book of the Nicomachean Ethics, new categories began to be used in order to describe friendship. ${ }^{12}$ According to Aristotle, citizenship is an expression of friendship, as it is based on a free choice of cohabitation and collective action. This

7 Boncompagno da Signa was certainly the most vehement critic of Cicero. He was a magister of grammar and rhetoric in Bologna during the first decades of the thirteenth century. Boncompagno thought he had to compose a new Rhetorica because his students were no longer interested in Cicero's texts; cf. Boncompagno da Signa, Rhetorica nouissima, prol.: Rhetorica compilata per Tullium Ciceronem iudicio studentium est cassata, quia numquam ordinarie legitur, immo tamquam fabula uel ars mechanica latentius transcurritur et docetur ("In the judgement of the students, the rhetoric put together by Cicero is inane, wherefore it is never ordinarily read in lecture, or rather it is very obscurely taught and glossed over like a fable or a mechanical art”, transl. Carruthers/Ziolkowski 2002, 103).

8 Cox 2006; Grévin/Turcan-Verkerk 2015.

9 For the Franciscan Salimbene de Adam, for example, Cicero embodied the third art of the triuium, cf. Salimbene de Adam, Cronica 552: Sed nec gramatica, nec dialetica, nec flores Tullii quos erudierant a morte liberant huius exili ("But neither grammar, nor dialectic, nor Cicero's flowers freed from the death of this exile those whom they educated").

10 From a Florentine corpus, Black 2001, 197, 211-212 concludes that Cicero's moral essays were not studied in classrooms during the thirteenth and fourteenth centuries. According to him, they began to be used for educational purposes in Italy in the fifteenth century.

11 For instance, De amicitia was read as encouraging the love of God's creatures and caritas. Cf. Fuchs 2013.

12 Sère 2007, 35-38, 76-83, 401-402. 
new source incited some communal authors to express political rules in terms of friendship. ${ }^{13}$ The reception of De officiis developed in a similar way, since it progressively formed the underpinning of the reading of Aristotle's texts. In contrast to this, De senectute was rarely quoted, but it was nevertheless frequently copied as a complement of De amicitia.

In addition to these texts-to which we can add Somnium Scipionis, Paradoxa Stoicorum, and Tusculanae disputationes-Cicero was also known through intermediaries. ${ }^{14}$ However, his historical character had been overshadowed as his correspondence was only found in the mid-fourteenth century and his speeches were rarely copied. The most famous event in his life was the Catilinarian conspiracy, as recorded in the work of Sallust. ${ }^{15}$ Similarly, the Catilinarian Orations were Cicero's speeches that were copied most often; equally successful was the fake invective addressed to Sallust. ${ }^{16}$ By the thirteenth century, the Caesarian speeches (Pro Marcello, Pro Ligario and Pro rege Deiotaro) gradually rivalled the Sallustian texts. ${ }^{17}$

Through this reduced corpus, Cicero appeared as a wise rhetorician concerned with the common good, and in a minor way as a guardian of Republican interests. During the fourteenth century, this image of Cicero was gradually changed because of the discovery of his political opinions and behaviours.

\section{The discovery of the senator behind the auctoritas}

By the second part of the thirteenth century, Cicero's link with political actionand especially with Caesar's power-was uncovered by new sources, which led to an update of existing interpretations of his life. In Italian comuni, the dictatores, authors of rhetorical and official writings such as notaries, chancellors, and masters of rhetoric, paid more attention to the political influence of Cicero the orator (which went together with an enhanced emphasis on his oratory as such).

In the 1260s, several authors, including the notary Brunetto Latini, the judge Bono Giamboni, and the teacher of rhetoric Guidotto da Bologna, described the

13 Artifoni 2006, 2012.

14 Cf. Schanz 1927, 546: “Im Mittelalter wurde Cicero mehr gepriesen als gelesen”.

15 Bolaffi 1949.

16 Novokhatko 2009, 3-26.

17 Parts of the Catilinarian Orations were translated into the Tuscan language before 1313. Similarly, the Caesarian Speeches were translated by Brunetto Latini during the second part of the thirteenth century. Cf. Guadagnini/Vaccaro. 
rules of eloquence in the vernacular. At the same time several anonymous commentaries on Ciceronian works gave a civic dimension to rhetoric, based on Inu. rhet. 1.1, and warned of the dangers of an orator lacking wisdom. ${ }^{18}$ In these commentaries Cicero was referred to in order to establish a kind of citizenship that was based on oratory: for the well-being of a community it became crucial to define rules for oratory. ${ }^{19}$ Shortly afterwards the re-evaluation of Cicero's biography in terms of exemplarity enriched this new political view. The narration of his life gradually evolved from the 1320s with the 'discovery' and the new use of ancient texts; it was also influenced by a new conception biography as a genre.

In educational literature, for example, the norms of the accessus (a short introduction addressed to student readers, presenting the text and the author's intentions) evolved gradually. By the twelfth century, the accessus focused on the work, so that information about the author was only relevant as long as it served the explanation of the text. Even when Cicero's political life was known, it was set aside in order to focus on his portrayal as author. ${ }^{20}$ The influence of Aristotle's theory of causation on the composition of accessus ${ }^{21}$ gave greater importance to the human faculties of the author. He became the efficient cause (causa efficiens) of the text, which transformed his role from being an authority

18 Prefaces of several commentaries asserted that political claims should be supposed by a perfect command of eloquence; see for example the Tuscan translation of Rhetorica ad Herennium, identified by its incipit Nel sesto dì (ms. Florence, Biblioteca Medicea Laurenziana, Plut. 43.6, fol. 1r) and the commentary of Trattatello di colori rettorici. Cf. Scolari 1984.

19 This public concern is also found in the introduction of the anonymous Fiore di rettorica, a vernacular version of the Rhetorica ad Herennium. The first version of this work presented Cicero as a protector of the city against a speech "dangerous as a sharpened knife in the hand of a madman" (Fiore di rettorica 1, in: Speroni 1994, 3-4: "E io, veggendo nella favella cotanta utilitade, sì mi venne in talento, a priego di certe persone, della Rettorica di Tulio e d'altri detti di savi cogliere certi fiori, per li quali del modo del favellare desse alcuna dottrina. [...] la sua favella così è in lui pericolosa come uno coltello aguto e tagliente in mano d'uno furioso").

20 For instance, in an introduction to De officiis (ms. Milan, Biblioteca Ambrosiana, F 42 sup, fol. 36r-36v): Tullius uidens romanam rem publicam uiciis quorundam Romanorum [lacuna] postposuit curam rei publicae et adhesit studio philosophie. Sciens igitur a uiciosis quibus resistere non ualebat non posse regi ciuitatem super quam maximam curam habebat. Maluit tractare de huius modi genere philosophie per quod posset eos reuocare a uiciis quam de alio. Ad quod maxime ualebat tractatus de officiis. ("Seeing that the Roman Republic was [flawed] by the vices of some Romans, Cicero set aside his care for the state and turned to the study of philosophy. He knew that the Republic, for which he had cared so much, could not be governed by vicious people against whom he was not strong enough to resist. Therefore he chose to deal with the kind of philosophy with which he could revoke them from their vices and the rest. This is the main aim of De officiis.”).

21 Minnis 1984, 27-29. 
into that of creating agens. At the same time, the encyclopaedias of the thirteenth century presented Cicero as a citizen in a specific historical setting. Among them, Brunetto Latini's Tresor was one of the more successful compendia in Italian comuni. Latini depicts Cicero as a brave senator, encouraged by Cato-a symbol of virtue-to discourage his opponents with words and with force. ${ }^{22}$ Latini's use of Cicero is symbolic: despite his admiration for him, he favours references to other characters, especially Caesar. This hints at a more general tendency: in medieval literature the senator 'Cicero' remained only a secondary character, while the rhetorician and philosopher 'Tullius' was an ever-present point of reference. ${ }^{23}$

The first independent biographical text on Cicero is an introduction to a compilation of his works copied in Verona c. $1330 .{ }^{24}$ The anonymous biographer elaborates at length on Cicero's humble origins and his involvement in the defeat of Catiline. ${ }^{25}$ The emphasis on Cicero's supposed poverty in early life on the one hand helps to give prominence to his merits and on the other hand to depict Catiline as a wicked nobleman. Also in other communal sources the historical character Cicero was presented as the symbol of a homo nouus who supported measures against old families. ${ }^{26}$ In this context, this first biography, in spite of representing a new literary format, gathered widely-known elements about Cicero. Until the mid-fourteenth century, any political portrait of Cicero was meant to provide details about his intentions rather than his actions: a medieval reader did not have explicit knowledge of Cicero's senatorial practices, but regarded him as a figure of high authority in establishing the norms of a stable civic life.

A watershed occurred in 1345 when Petrarch read the letters Ad Atticum for the first time. By entering the private life of Cicero, he discovered Cicero's opportunism and his thirst for acknowledgment. As the correspondence sometimes opposed the morals of the philosopher, it caused a passionate debate between some authors of the fourteenth century regarding Cicero's choices and, more generally, the role of philosophers in the city. Petrarch was especially vehement and addressed a famous letter to Cicero to express his distress. ${ }^{27}$ Similarly, the

22 Brunetto Latini, Tresor, 1.36.5, 3.35.6.

23 For example, in the Speculum historiale of Vincent of Beauvais, among the 129 sections devoted to the period from $48 \mathrm{BCE}$ to $15 \mathrm{CE}, 25$ sections are dedicated to Tullius and only one to Cicero. Cf. Draelants 2004.

24 Ciceronis Vita Trecensis, in: Tilliette 2003. The author used the Church Fathers, Sallust, Seneca and Valerius Maximus, the Anthologia Latina and some information extracted from Cicero's works.

25 For example, Cicero was alleged to be the son of a blacksmith. Cf. Ciceronis Vita Trecensis, in: Tilliette 2003, 1064.

26 Osmond 2000.

27 Petrarch, Fam. 24.3. 
letters of Cicero offered material for a new critical appraisal of the Roman Civil War. Through these letters, the role of several characters in these events were reevaluated, and the debates echoed contemporary political debates, notably on the rightful ruler. ${ }^{28}$

\section{Identifying the tyrant}

\section{How to define tyranny?}

The debate on how to define tyranny escalated in communal literature during the fourteenth century, in connection to a changing political geography. Debates focused on the legitimacy of despotic power and, especially, on the methods to remove it. Aristotle's work greatly contributed to this debate. As Claudio Fiocchi has highlighted, the 1260s were a pivotal moment for the change from a theological to a political definition of tyranny. ${ }^{29}$

Previously the tyrant was defined as a ruler who disrespected God's laws, of which he was supposed to be the protector. ${ }^{30}$ Thus, tyranny was the outcome of a moral weakness that raised theological questions. In contrast, Aristotle proposed that tyranny was not an individual deficiency but an unfavourable evolution of a specific type of government: the monarchy. ${ }^{31}$ Tyranny was not a moral problem; it demonstrated that the institution was perverted and that the wrong rulers had been elected. ${ }^{32}$ This new definition of tyranny also gave a new role to the ruled people. The Christian tradition had recommended submission. According to Paul, "there is no authority, except from God". ${ }^{33}$ That is why, traditionally, medieval theologians established that a lawfully vested ruler should be respected, even if he became unworthy.

As a result of the sketched change, from the 1260s onwards several definitions of tyranny existed, which I describe here as civic (the ruler disrespects the common weal), pathos-laden (the ruler yields to hybris), and legal (the ruler disrespects sovereignty):

1. In De regno, Thomas Aquinas associated tyranny with the depreciation of the common weal: the ruler considered the interests of the community below his

28 Cf. recent treatments of the theme by Hermand-Schebat 2011; Casale 2013b; Boldrer 2019.

29 Fiocchi 2004, 66-68.

30 Canning 1987, 17-21.

31 Bodéüs 1999.

32 Arist. Pol. 5.10.

33 Rm. 13:1. 
own. ${ }^{34}$ Following the Aristotelian classification of governments, Thomas viewed tyranny as a perverted monarchy. According to him, the personality of a ruler did not make him a tyrant over time; it was the institutions and the nonchalance of the community that allowed this behaviour. Institutional protection for Italian communities became more important at the end of the thirteenth and the beginning of the fourteenth centuries, a time of political turbulence. On the one hand, the allegation of tyranny was a political strategy in the factional opposition between Guelphs and Ghibellines. ${ }^{35}$ As showed by Rosa Maria Dessì, in Florence the Guelphic faction built its civic identity by opposing despotism after 1260: therefore, it described the actions of the Ghibellines as tyrannical operations. ${ }^{36}$ On the other hand, some of the comuni evolved into urban lordships (signorie).

2. Misuse of power could rapidly contaminate the exercise of such personal or family authority. For example, Ezzelino da Romano, who ruled in Verona, embodied a pathos-laden concept of tyranny from the mid-thirteenth century. ${ }^{37}$ With such characters, this political topic became the object of storytelling. In 1313, Albertino Mussato in his Ecerinis transformed Ezzelino into a tragic figure, tormented by his hunger for power and condemned to divine punishment. The Ecerinis departs from Aquinas' definition of tyranny, which becomes a psychological and temperamental feature and manifests itself in mindless acts and cruelty. With Mussato, tyranny was equalled to a constant fear of a massacre; ${ }^{38}$ from the depreciation of the common weal it turned into an attack against the people. Mussato created an esthetical model of tyranny inspired by Seneca's tragedies. A similarly bloody depiction of despotic government appeared in Petrarch's De remediis utriusque fortunae in 1367. In a dialogue, Reason blames the happy ruler

34 Thomas Aquinas, De regno 1.3 (in: Carron 2017, 110-111).

35 From the end of the twelfth century, two partes emerged in the conflict between the Pope and the Holy Roman Emperor. The Guelphs supported the former, the Ghibellines the latter. Over time, independently of the conflict of universal powers, these partes were used for forming opposition or coalition between cities.

36 See, for example, the statement of Matteo Villani in his Cronica, written after 1348: "The Guelphic part is indeed the base and the building block of the Italian freedom, opposed to all tyrannies. So that if a Guelph becomes a tyrant, he becomes Ghibelline, as experience has shown”. Cf. Dessì 2005, 36-39; 2011, 29.

37 Canning 1987, 35-36. Ezzelino became the medieval counterpart of Nero, who embodied Roman tyranny during the Middle Ages. Cf. Bjaï/Menegaldo 2009.

38 Cf. Albertino Mussato, Ecerinis 117-123: Nescitis cupidi nimis / quo discrimine queritis / regni culmina lubrici: / diros expetitis metus, / mortis continuas minas. / Mors est mixta tyrannidi, / non est morte minor metus ("In your excess of desire you know not the danger that besets your quest for the slippery heights of power. It is dreadful fears you chase after and unending threats of death. Death is inseparable from tyranny, nor is fear something less than death", transl. Grund 2011). 
who asserts to exercise tyrannis by pointing out his immorality: "Your power is plundering and slaughter; you glut yourself on gold and blood, like a jackdaw, greedy for gold, clings to its loot, or like the leech, who does not relinquish the skin unless he is full with blood" ([GAVDIUM:] "Tyrannidem in ciues exerceo". [RATIO:] "Predam atque carnificiam, auro implendus et sanguine, auri sitiens monedula tenaxque, nec missura cutem nisi plena cruoris hirudo"). ${ }^{39}$

3. The controversy over the universal power of the Empire and the Church encouraged thinkers to define tyranny in legal terms. By the late thirteenth century, jurists reflected on the possibility to depose illegitimate power. In the middle of the fourteenth century, tyranny became the topic of specialised treatises that established tyranny as an usurpation of sovereignty. According to the professors of law Bartolo da Sassoferrato and Baldo degli Ubaldi, a tyrant is a ruler who imposes his authority at the expense of a legitimately existing power. Only this legitimate power could legally act against the tyrant. ${ }^{40}$ According to Bartolo, usurpation of sovereignty was an attack on the ciuitas, while for Baldo it was one on providence (thus, Baldo combined a legal and a theological definition of tyranny). ${ }^{41}$

During the fourteenth century, these three different definitions coexisted and were sometimes merged. In De tyranno, for instance, Coluccio Salutati defined tyranny as a power obtained by one or several persons through usurpation, or a ruler who consciously commits injustices. ${ }^{42}$ More generally, as Aristotle had defined tyranny as the harmful part of monarchy, there was a risk of despotism when choosing this type of government. Does individual power facilitate tyrannical behaviour? Would it be safer to impose a collective form of power? Questions like these triggered a lively debate, as shown by the contradictory words of some works written by more than one author. For instance, in De regno, composed for the King of Cyprus, Thomas Aquinas explained that a monarchy, even a despotic one, was better than the risks of conflict caused by an oligarchy. ${ }^{43} \mathrm{Nev}$ ertheless, the Dominican Bartholomew of Lucca, when completing Thomas' opera, associated monarchy with tyranny when he divided types of government into two groups: regimen despoticum and regimen politicum. Bartholomew defined the 'political' regime (or politia) as a collective government. ${ }^{44}$ In contrast, he combined individual governments within the category 'despotic' regime. By

39 Petrarch, Rem. 1.95.7-8.

40 Canning 1987, 225-226; Fiocchi 2004, 125-130.

41 Quaglioni 1980, 68-69.

42 Salutati, Tyr. 1.8 (in: Baldassarri 2014, 78). Cf. Turchetti 2001, 300-301.

43 Thomas Aquinas, De regno 1.5 (in: Carron 2017, 124-125). Cf. Lamy 2013, 256-259.

44 Black 2010, 51. 
mentioning biblical authorities, Bartholomew affirmed that monarchy is legitimate but that a political regime would be preferable. ${ }^{45}$ Accordingly, he proposed a geographical, historical, and hierarchical theory of governments, concluding that Italy was specifically intended to develop republicanism. ${ }^{46}$ Unlike Aristotle and Plato-who are frequently quoted by Bartholomew-Cicero is rarely mentioned as a source for establishing such a constitutional hierarchy. His case is representative: generally Cicero's political life is rarely connected to the debates on tyranny, even though some medieval authors identified Julius Caesar as a despot.

\section{Cicero, Caesar, and the Civil War}

Authors in the Renaissance dedicated full pages to Julius Caesar's ambition and his dramatic death. In contrast, Caesar entered the narrative scene in medieval literature only at a late stage, at the beginning of the thirteenth century. ${ }^{47} \mathrm{He}$ was given the courteous image of a conqueror and virtuous knight, a model of a victorious military leader. ${ }^{48}$ As conveyed by Augustine, Caesar also appeared as the creator of the Roman Empire.

Medieval texts that mention Cicero and Caesar together focused on their military feats in Gaul: they did not distinguish between Marcus Tullius and his brother Quintus. ${ }^{49}$ At the same time, Cicero's actions during the Civil War received little attention, except in the literary overview of Brunetto Latini, who stressed several times the damage Caesar's ambitions caused to the Republic. Brunetto assessed Cicero's political position through his Caesarian speeches Pro Marcello, Pro Ligario, and Pro rege Deiotaro. Being inspired by these texts, Brunetto praised the merits of Pompey and emphasized the selfishness of his opponent. He thereby established a dualist vision of this confrontation, contrasting the sound stability of collectivity to the dangerous impulsiveness of individual

45 Bartholomew of Lucca, De regno 6.1.

46 Blythe 2005, 156-171.

47 Croizy-Naquet 2006, 39.

48 During the Middle Ages, Caesar was not considered as an author. Up to the second half of the fourteenth century, De bello Gallico was attributed to Suetonius or to an anonymous grammarian.

49 This confusion was for instance transmitted by the successful Faits des Romains, a French compilation of Roman historians, and by the Speculum historiale of Vincent of Beauvais. 
ambition..$^{50}$ In Rettorica, Brunetto insists that Caesar was harmful and asserts that Cicero's involvement with Pompey was for the sake of the Republic:

\begin{abstract}
Nella guerra di Pompeio e di Julio Cesare si tenne con Pompeio [sc. Cicerone], sicome tutti 'savi ch'amavano lo stato di Roma; e forse l'appella nostro comune però che Roma èe capo del mondo e comune d'ogne uomo. ${ }^{51}$

During the war between Pompey and Caesar, he supported Pompey, like every wise man who loved Rome did. He calls Rome 'our comune', maybe because Rome is the head of the world and comune of every man.
\end{abstract}

Because of his universalistic take on Roman history, Brunetto applied statements like these to the present. He encouraged the reader to interpret the Caesarian threat as a metaphoric menace facing each Italian comune. Such a historical argument supported Brunetto's Guelphic position. ${ }^{52}$ More than once he refers to the superiority of communal power over any individual power. ${ }^{53}$ Brunetto condemned Caesar for seizing power against the advice of the Senate and for his legal practice, which he considered unfair. When he popularized the Caesarian speeches, Brunetto presented Cicero as a protector of just causes and guardian of the common good. According to him, as a spokesperson Cicero defended men of great political and moral qualities. Deiotarus, accused of instigating Caesar's assassination, is described as a "great and noble" man ("in difensione del grande e gentile uomo Deiotaro"), "friend of the comune and the Roman Senate" ("lo quale sempre era stato amico del commune e del sanato di Roma"). ${ }^{54}$ By defending these people, Cicero demonstrated his commitment to legitimate power. Through the case of Cicero, Brunetto judged political and communal behaviour and proposed the most updated interpretation of the confrontation between Cicero and Caesar of the thirteenth century. His viewpoint remained an exception for at least two more generations.

Outside the Italian comuni, a hostile description of Caesar existed from the twelfth century onwards. In the 1150s, for instance, John of Salisbury described him as a tyrant, who governed by violence and was murdered with the agree-

50 Brunetto Latini, Tresor 1.36.6-38.1.

51 Brunetto Latini, Rettorica 1.

52 Brunetto Latini sustained the pro-papal Guelphic position against the imperial influence on Italian comuni, cause of his exile from Florence in 1260. In the Tresor, he describes Manfred, the pretender to the imperial crown, as a monster, an evil figure averse to God and reason. Cf. Carmody 1948, 79.

53 Brunetto Latini, Tresor 2.44.1.

54 Brunetto Latini, Per lo re Deiotaro (in: Lorenzi 2018, 229-230). 
ment of the Senate. ${ }^{55}$ In contrast, numerous works portray Caesar in a flattering light. During the 1260s, for example, the anonymous Fiore di filosofi described his government as a reign of clemency. ${ }^{56}$ This positive notion of Caesar and his government was predominant in literature for several decades, ${ }^{57}$ and Caesar's murder was not interpreted as tyrannicide. Dante wrote the most famous condemnation of his murderers: he compared Brutus and Cassius to Judas and placed them in the Inferno. He accused them of treason and irresponsibility because their action killed a man capable of providing weal to humankind. ${ }^{58}$

In contrast to Caesar, the medieval Cicero seemed to be neutral during the Civil War. ${ }^{59}$ In 1336, when Giovanni Colonna wrote a short biographic text about Cicero, he put Cicero in the Republican context through a series of jokes from Macrobius. ${ }^{60}$ He thereby describes Cicero as a character who played a uniting role in Republican conflicts. According to Colonna, Cicero was a peace broker without any political strategy. Moreover, immediately after Caesar seized power, Cicero devoted himself to a philosophical life far removed from the public space. ${ }^{61}$

In short, during the Middle Ages the conflict between Cicero and Caesar provided little space for any political assertiveness of Cicero through actions or theory. Although the restricted corpus of his works gave some essential information about Cicero's opinions on the choices made by Caesar, the medieval political debates rarely used them.

55 John of Salisbury, Policraticus 8.19.

56 Cf. Fiore di filosofi p. 23 Cappelli: "[Julio Cesare] fue avventuroso in tutte battaglie ch'egli fece, e fue lo primo imperatore ch'ebbe solo la signoria del mondo, e fue sì benigno che quelli ch'egli non vincea con arme vincea con clemenza e con benignità" ("Julius Caesar was adventurous in the battles he led, and he was the first emperor who governed the whole world alone; and he was so kind that the persons he did not conquer by weapons were conquered by his clemency and his kindness").

57 Ricci 1971; Russo 1987, 23-30.

58 Dante, Commedia, Inf. 34.64-69. See Sol 2005, 37-41.

59 See La Bua in this volume for a different conceptualization of his role in Antiquity.

60 Colonna uses excerpts from the second book of the Saturnalia, from a chapter devoted to famous jokes of Cicero.

61 Giovanni Colonna, De uiris illustribus (in: Ross 1970, 562): Demum cum Cesar coniurantibus Bruto et Cassio et aliis senatoribus esset occisus et bellis ciuilibus iterum renascentibus, Tullius iam etate confectus in Tusculano suo secessit et otio uacabat et licteris, ut in quadam in Acticum amicum suum epistula refert. ("When Caesar was murdered by the conspirators Brutus and Cassius and by other senators, and when the civil war broke out again. Cicero, already old, withdrew to his villa in Tusculum and committed himself to otium and literature, as we can see in a letter addressed to Atticus”). 


\section{Cicero's thoughts and actions: an ambiguous legacy in the debate on rightful government}

\section{How Cicero legitimized tyrannicide}

The relative neglect of Cicero's political theory is surprising from a modern perspective; but it is also remarkable if one thinks of medieval reading canons. In De officiis, Cicero underlined the mistakes Caesar made in his strife for personal power. ${ }^{62}$ His most vigorous assertion against tyranny is found in book 3 :

Nulla est enim societas nobis cum tyrannis et potius summa distractio est, neque est contra naturam spoliare eum, si possis, quem est honestum necare, atque hoc omne genus pestiferum atque impium ex hominum communitate exterminandum est. ${ }^{63}$

We have no ties of fellowship with a tyrant, but rather the bitterest feud; and it is not opposed to Nature to rob, if one can, a man whom it is morally right to kill; nay, all that pestilent and abominable race should be exterminated from human society.

This text on the legitimization of tyrannicide was written a few months after Caesar's murder. According to Cicero, the necessary liberation of a community from despotic power justifies violence and murder. But even if De officiis was famous during the Middle Ages, authors rarely referred to this excerpt. Bartholomew of San Concordio quoted it in his Documenta antiquorum and translated it into the vernacular between 1302 and 1308 for the banker Geri degli Spini, the head of the Black Guelphs of Florence. ${ }^{64}$ More generally, the Christian tradition supported a restricted reading of this excerpt. Aquinas, for example, alluded to it in his commentary In quattuor libros Sententiarum and partly contrasted it:

Nullus tenetur ei obedire quem licite, immo laudabiliter potest interficere. Sed Tullius in libro De officiis saluat eos qui Iulium Caesarem interfecerunt, quamuis amicum et familiarem, qui quasi tyrannus iura imperii usurpauerat. Ergo talibus nullus tenetur obedire. ...

62 Cf. Cic. Off. 1.26: Nam quidquid eiusmodi est, in quo non possint plures excellere, in eo fit plerumque tanta contentio, ut difficillimum sit seruare sanctam societatem. Declarauit id modo temeritas C. Caesaris, qui omnia iura diuina et humana peruertit propter eum, quem sibi ipse opinionis errore finxerat principatum. ("Whenever a situation is of such a nature that not more than one can hold preeminence in it, competition for it usually becomes so keen that it is an extremely difficult matter to maintain a 'fellowship inviolate'. We saw this proved but now in the effrontery of Gaius Caesar, who, to gain that sovereign power which by a depraved imagination he had conceived in his fancy, trod underfoot all laws of gods and men”, transl. Miller 1913).

63 Cic. Off. 3.32, transl. Miller 1913.

64 Nannucci 1840, 343. 
Tullius loquitur in casu illo quando aliquis dominium sibi per uiolentiam surripit, nolentibus subditis, uel etiam ad consensum coactis, et quando non est recursus ad superiorem, per quem iudicium de inuasore possit fieri: tunc enim qui ad liberationem patriae tyrannum occidit, laudatur, et praemium accipit. ${ }^{65}$

If it is a legitimate and even a praiseworthy deed to kill a person, then no obligation of obedience exists toward that person. In De officiis, Cicero justifies Caesar's assassins. Although Caesar was a close friend of his, yet by usurping the Empire he proved himself to be a tyrant. Therefore, toward such powers there is no obligation of obedience. Cicero speaks of domination obtained by violence and ruse, the subjects being unwilling or even forced to accept it and there being no recourse open to a superior who might pronounce judgement upon the usurper. In this case he that kills the tyrant for the liberation of the country, is praised and rewarded.

Following Pauline precepts, each Christian has to obey secular powers, including despots. ${ }^{66}$ According to Aquinas Cicero was correct, but only for the specific case of a tyrant (for Thomas, this means a ruler who negates the common weal) who has usurped the power by violence. Thomas moderated his interpretation a few years later in De regno by suggesting that a community can eliminate its ruler by dismissal and not by murder if he has betrayed collective happiness. As a corroboration of his argument Thomas insisted on the non-apostolic nature of tyrannicide. ${ }^{67}$

Only a few authors continued, opposed or even quoted Cicero's arguments on tyrannicide, although numerous theologians and jurists used Thomas' corpus. Even Lucas de Penna, a supporter of tyrannicide, when commenting on

65 Thomas Aquinas, Scriptum super Sententiis II. Dist.44, q.2, a.3 (transl. Dominican House of Studies). For tyranny in Thomas Aquinas see Morgain 2005.

66 Ibid., q.2 a.2. Cf. Turchetti 2001, 252-273.

67 Thomas Aquinas, De regno 1.7 (in: Carron 2017, 134-139): Et si sit intolerabilis excessus tyrannidis, quibusdam uisum fuit ut ad fortium uirorum uirtutem pertineat tyrannum interimere, seque pro liberatione multitudinis exponere periculis mortis. [...] Sed hoc apostolicae doctrinae non congruit. [...] Videtur autem magis contra tyrannorum saeuitiam non priuata praesumptione aliquorum, sed auctoritate publica procedendum. Primo quidem, si ad ius multitudinis alicuius pertineat sibi prouidere de rege, non iniuste ab eadem rex institutus potest destitui uel refrenari eius potestas, si potestate regia tyrannice abutatur. ("If the excess of tyranny is unbearable, some have been of the opinion that it would be an act of virtue for strong men to slay the tyrant and to expose themselves to the danger of death in order to set the multitude free. [...] But this opinion is not in accordance with apostolic teaching. [...] Furthermore, it seems that against the cruelty of tyrants an action must rather not be undertaken through the private presumption of few people, but with public authority. First, if to provide oneself with a king belongs to the right of any multitude, it is not unjust that an installed king be deposed or have his power restricted by that same multitude if he abuses the royal power in a tyrannical way."). Cf. Fiocchi 2004, 68-87. 
the Corpus iuris ciuilis in the 1350s, only quoted De amicitia about the despot. He restrained from using Ciceronian propositions in favour of moral considerations:

\begin{abstract}
"In uita quippe tyrannorum nulla fides, nulla pietas, nulla spes, nulla charitas, nullus beniuolentie locus, omnia semper suspecta atque sollicita sunt. Quis enim eum diligat quem metuit: aut eum a quo se metui putat?” (Cic. Sen. 52-53) Tyrannus uir est deceptionis illudens, detractionis artifex, figulus falsitatis, qui dolum dirumque nephas semper sub pectore uersat, dixit Tullii liber De amicitia. ${ }^{68}$

"In the life of tyrants, there can be no faith, no hope, no affection, no place for goodwill; every act arouses suspicion and anxiety. For can anyone love either the man whom he fears, or the man by whom he believes himself to be feared?” The tyrant plays with deceit. He is a master of slander, a shaper of lie, who turns over in his mind trickery and dire sacrilege, as Cicero said in De amicitia.
\end{abstract}

This excerpt from De amicitia was common, in contrast to Cicero's quotes on tyranny in De officiis. For instance, it was chosen by the jurist Alberico da Rosciate in his commentary of the Corpus iuris ciuilis in order to complement Seneca's ethical considerations about tyranny. ${ }^{69}$

The discovery of a large part of Cicero's biography during the fourteenth century usually associated him with tyrannicide, but it did not automatically lend his political thoughts more credibility. The first humanists temporarily blackened Caesar's reputation. On the basis of Cicero's and Suetonius' works, Petrarch at first took a dim view of Caesar's personality. ${ }^{70}$ He celebrated his victories, but condemned him for creating the absolute power of imperial times. ${ }^{71}$ However, the reading of Cicero's letters excluded any enthusiasm for his political activities and queried his judgment on politics. As a result of this discovery, Petrarch also reconsidered Caesar's attitude: after writing the Africa he even admired him. ${ }^{72}$ Boccaccio adopted this interpretation and considered the conflict between Cicero and Caesar to be an exaltation of Caesar's magnanimity. Because Caesar had for-

68 Lucas de Penna, Super tribus libris Codicis (Lucas da Penna 1529, fol. 333v). For the (almost verbatim) quotation from Cicero I have used the translation of Falconer 1923 (slightly adapted). Lucas states that it is illegal to kill a tyrant, but that it is fair. He uses biblical examples to argue this point. Cf. D’Addio 1987, 519.

69 Quaglioni 1979, 93-95.

70 Petrarch, Africa 2.228-237. Cf. Martellotti 1947.

71 Cavagna 2007, 73.

72 Ibid., 74. As Hermand-Schebat has shown, Petrarch's judgment on Caesar gradually evolved. In the 1340s, when he was supporting Cola di Rienzo in Rome, Petrarch was opposed to individual power. In contrast, during the 1360s, after Galeazzo II Visconti had sponsored him, he expressed his disappointment with Republican institutions and was more lenient with Caesar. Cf. Hermand-Schebat 2013. 
given Cicero and accepted his return to Rome after Pompey's defeat, Boccaccio saw in Caesar a pagan forerunner of Christian forgiveness. ${ }^{73}$ In contrast, Cicero had been ungrateful by participating in Caesar's murder, although Caesar had been merciful to him. That is why, according to Boccaccio, Mark Antony assassinated Cicero: it was a result of his shameful decision. ${ }^{74}$

The writings and actions of Cicero gained a new scope in late medieval Italy when the first humanists used the example of the Roman Republic to describe the struggles between several communal and seigneurial expanding powers.

\section{Late medieval echoes of the denunciations of Cicero}

The judgment of Cicero in comparison to Caesar fuelled several debates at the end of the fourteenth century, in the context of the conflicts between Florentine Republican ideals and seigneurial powers. In 1394, Pier Paolo Vergerio condemned Caesar "for forsaking the public good to satisfy his own desires". ${ }^{75}$ His answer to Petrarch's attacks on Cicero was inspired by an earlier (undated) response to Petrarch, written by the canonist Francesco Zabarella in order to prove that Cicero had acted rationally. ${ }^{76}$ According to him, a philosopher could never lose interest in civic life. ${ }^{77}$ Zabarella postulated the superiority of the Republican system and asserted that Cicero had always hated Caesar. This meant that Cicero was not inconsistent: when he sometimes praised Caesar, he did so with the only objective of maintaining cohesion within the Republic. In Zabarella's view, Cicero was not unfaithful, but a pragmatic politician.

In 1392, Coluccio Salutati's reading of the letters Ad familiares influenced his lukewarm reception of Cicero's opinions about the murder of Caesar. Eight years later he wrote his De tyranno as a response to a question by his friend Antonio dell'Aquila on the legitimacy of Visconti's expansion against Florence. ${ }^{78}$ In the treatise Salutati supported Dante and his condemnation of Brutus and Cassius. ${ }^{79}$ At the same time he questioned Cicero's position on political murder. However,

73 Boccaccio, Esposizioni sopra la Comedia 4.litt. 193. Cf. Branca 1990, 204-205.

74 Boccaccio, Esposizioni sopra la Comedia 4.litt. 330 - 331.

75 Pier Paolo Vergerio, Epistolario = Smith 1934, 436: Placuit siquidem Cesar quandiu sibi incolumitas urbis et ciuile otium placuit; postea uero quam subuertit omnia et libidine sua potitus est, nequaquam de eo bene dixi, partly quoted by Lee 2018, 163. Cf. also McManamon 1996, 52-59.

76 Sottili 1973, 38-39, 55.

77 Ibid., 57.

78 Zancarini/Fournel 1999, $50-53$.

79 Piccolomini 1991, 51-56. 
he used the historical character of Cicero, not his philosophical opinions. Salutati believed that tyrannicide was right, except for people who are "used to suffer cowardice" (populo per ignauiam patiente), ${ }^{80}$ but he refused to portray Caesar as a despot. According to him, Caesar's ambition was permissible, despite Cicero's portrait of Caesar. ${ }^{81}$ Whereas before 1392 Salutati had depicted Caesar as a historical example of Visconti's tyranny, ${ }^{82}$ in De tyranno he explained why Cicero's political statements against Caesar were not reliable: firstly because Cicero only made these claims after Caesar's death, ${ }^{83}$ and secondly because Cicero's positions would have been different if Pompey had won. ${ }^{84}$ Thus, Salutati criticized Cicero's opportunism and his lack of strength:

Verum, ut de Policratico sileam, Cicero noster ab academiae, quam colebat, institutione nimis assumpsit ex tempore loqui, nec solum nunc hoc nunc illud dicere, sed contraria mutatione temporum affirmare. Forte quidem qui diligenter ipsius scripta perspexerit, longe maiores Caesaris laudes inueniet quam detractiones; ferme quidem numquam eum uituperat quin et laudet uel extenuet aliqualiter acrimoniam inuehendi. ${ }^{85}$

Truly, to leave aside the Policraticus, this Cicero of ours, according to the teaching of the Academy which he followed, took upon himself to speak too much offhand, saying now this and now that and contradicting himself as circumstances changed. It may well be that a careful examination of his writings would show far greater praise of Caesar than blame. Certainly Cicero never attacks Caesar without at the same time praising him or somewhat modifying the violence of his invective.

Salutati had doubts about Cicero's abilities because as a senator he had been unable to predict the public's attachment to Caesar. ${ }^{86}$ Despite Cicero's omnipresence in the text, it appears that Salutati did not give him any important argumentative function with regard to tyranny. Even though scholars who in the footsteps of Baron defend the idea of a "civic humanism" have interpreted the quotations from Cicero as part of a debate on Republican liberty and tyranny, other scholars have suggested that above all they are concerned with public involvement (within a broader reflection on Republican liberty). ${ }^{87}$ In some ways,

80 Salutati, Tyr. 2.8 (numbering according to Baldassarri 2014).

81 Salutati argues pragmatically that monarchy can be better than other types of government if it provides peace; cf. his Letter to King Charles VI of France 6 (in: Baldassarri 2014, 52). He thinks that Caesar's dictatorship had such a role, too.

82 De Rosa 1980, 135, 158-159.

83 Salutati, Tyr. 3.1.

84 Casale 2013a.

85 Salutati, Tyr. 3.3 (transl. Baldassarri 2014).

86 Salutati, Tyr. 4.4.

87 McManamon 1996, 57. 
Cicero continued to be associated with moral and pragmatic commitments rather than with political theory.

The debate on tyranny illustrates the limits of Ciceronian influence on medieval political thought. Even though Cicero left many texts on tyranny, their impact was marginal during the Middle Ages. Some vanished from scriptoria, such as De re publica, whereas others, despite their availability, were almost ignored by jurists and polemists. This can be explained by the role that the medieval tradition attributed to Cicero's authority (a role that also persisted when Aristotelian texts increasingly circulated): besides a rhetorician, Cicero was a moral philosopher. As such, his texts were deemed to be relevant to guide both individual and collective social behaviour, but they were considered as useless for establishing constitutional rules. The primary influence of Cicero on political thought appears through civic norms: how to be useful to the community, and how (as an orator) to be an involved citizen. 